\title{
WestVirginiaUniversity
}

THE RESEARCH REPOSITORY @ WVU

Graduate Theses, Dissertations, and Problem Reports

2006

\section{American Standard}

John A. Pascarella

West Virginia University

Follow this and additional works at: https://researchrepository.wvu.edu/etd

\section{Recommended Citation}

Pascarella, John A., "American Standard" (2006). Graduate Theses, Dissertations, and Problem Reports. 1782.

https://researchrepository.wvu.edu/etd/1782

This Thesis is protected by copyright and/or related rights. It has been brought to you by the The Research Repository @ WVU with permission from the rights-holder(s). You are free to use this Thesis in any way that is permitted by the copyright and related rights legislation that applies to your use. For other uses you must obtain permission from the rights-holder(s) directly, unless additional rights are indicated by a Creative Commons license in the record and/ or on the work itself. This Thesis has been accepted for inclusion in WVU Graduate Theses, Dissertations, and Problem Reports collection by an authorized administrator of The Research Repository @ WVU. For more information, please contact researchrepository@mail.wvu.edu. 


\title{
American Standard
}

\author{
John A. Pascarella
}

A Thesis Submitted to the College of Creative Arts

At West Virginia University

In partial fulfillment of the requirements

For the degree of

\author{
Master of Fine Arts \\ In \\ Inter-Media
}

\section{Alison Helm, MFA, Chair \\ Young Kim Joseph Lupo \\ Kristina Olson}
Morgantown, West Virginia
2006

Keywords: Photography, Narrative, Image, American, Story 


\section{Abstract}

\section{American Standard}

\section{John A. Pascarella}

The work included in my MFA thesis exhibition entitled "American Standard" examines our role as narrative-based individuals within the American culture. In this current body of work I use the photographic image as a director uses the medium of film (moving image). Location scouting, casting, lighting, directing, editing, and processing all become intricate parts of the work, all to lead to a single solitary frozen moment in time that I believe creates a story. Story as created not in a fictional sense, but more in the vein of creative non-fiction, as the stories I tell come from a personal past. I ask the viewer to examine each photographic image, and examine its narrative fidelity. I would like the viewer to begin to become aware of their inherent attraction to narrative and that which unfolds because of that attraction. 


\section{Table of Contents}

Acknowledgements $\quad$ iv

List of Figures $\quad$ v

Introduction 1

"Homo narrans" 2

“American Standard” 8

$\begin{array}{ll}\text { Influential Artists } & 14\end{array}$

$\begin{array}{ll}\text { Conclusion } & 16\end{array}$

$\begin{array}{lr}\text { Figures } & 17\end{array}$

Bibliography 25

$\begin{array}{ll}\text { Resume } & 26\end{array}$ 


\section{Acknowledgments}

I would like to thank my wife Allison Pascarella, and family for their support over the span of the last three years. I would like to thank my mother Deborah, and father John Pascarella again for everything else leading up to this moment including the skills passed down to me that have allowed me to explore ideas and not be afraid of them. I cannot express enough gratitude to my graduate committee Alison Helm, Young Kim, Joseph Lupo, and Kristina Olson for their continued support, advice, availability, and friendship while pursuing my M. F. A. degree, your knowledge and guidance has been greatly appreciated. 


\section{List of Figures}

John A. Pascarella:

2) p. 10 Untitled (woman in rose dining room)

30 " x 40"

Chromogenic Print

2006

3) p. 12 Untitled (man with gun)

30 " x 40"

Chromogenic Print

2006

4) p. 13 Untitled (woman in blue shirt)

30 " x 40"

Chromogenic Print

2006

5) p. 14 Untitled (man at door with shoes)

30 " x 40"

Chromogenic Print

2006

Joe Rosenthal:

1) p. 32 Raising of the Flag on Iwo Jima

1945

Gregory Crewdson:

6) p. 45 Drowned Ophelia

48 " x 60"

Chromogenic Print

2001

Jeff Wall:

7) p. $48 \quad$ Milk

$1870 \mathrm{~cm} \times 2290 \mathrm{~cm}$

Light box

1984

Cindy Sherman:

8) p. $50 \quad$ Untitled Film Still \#10

8" x 10"

Silver Gelatin Print

1978 


\section{Introduction}

The photographs included in the "American Standard" series are personal accounts. These accounts are recreated with the medium of photography using techniques and influences of other narrative-based media. The images should be seen not only as a challenge to the truthfulness of the photographic image, but begin to question our perception of reality, where it comes from, and how accurate it really is. With the "American Standard" series I attempt to create ambiguous narratives that are also visually seductive. The intention of this body of work is to help the viewer analyze their inherent attraction to the photographic image, and the narrative. 
"Homo narrans"

Many different root metaphors have been put forth to represent the essential nature of human beings: Homo faber, Homo economicus, Homo politicos, Homo sociologicus, "psychological man," I propose that Homo narrans be added to the list.

- Walter Fisher, Human Communication as Narration

The author, theorist, and professor Walter Fisher (Ph. D. University of lowa, 1960) proposes that human beings are nothing more than story telling animals in his 1987 book Human Communication as Narration ${ }^{1}$. In this text Fisher offers what would be referred to as the narrative paradigm, when existence becomes narrative. Fisher offers this in relation to the idea that narrator be the master metaphor that describes humans (Homo narrans). When narration is taken as the master metaphor, it subsumes the others. The other metaphors become conceptions that inform various ways of recounting or accounting for human choice and action. Recounting takes such forms as history, biography, or autobiography. Accounting for takes such forms as theoretical explanation or argument.

${ }^{1}$ Fisher, Human Communication as Narration: Toward a Philosophy of Reason, Value, and Action, 62. 
Recounting and accounting for can be also expressed in poetic forms: drama, poetry, the novel and so on. Recounting and accounting for are, in addition, the bases for all advisory discourse. Regardless of the form they are given, recounting and accounting for constitutes stories we tell ourselves and each other to establish a meaningful life-world. The character or narrators, the conflicts, the resolution, and the styles will vary, but each mode of recounting and accounting for is but a way of relating a "truth" about the human condition. ${ }^{2}$

The items above in bold become my focus of interest and the way I perceive and apply this idea of the narrative paradigm in my tableaux imagery. Fisher offers this comparison of the narrative paradigm against a traditional model of rational.

Fisher's offerings look like this:

1. Humans are essentially story telling animals.

2. The paradigmatic mode of human decision-making and communication is "good reasons" which vary in form among situations, genres, and medial of communication.

3. The production and practice of good reasons are ruled by matters of history, biography, culture, and character.

4. Rationality is determined by the nature of persons as narrative beings-their inherent awareness of narrative probability, what constitutes a coherent story, and their constant habit of testing narrative fidelity, whether or not the stories they experience ring true with the stories they know to be true in their lives. (Narrative probability and

\footnotetext{
${ }^{2}$ Fisher, 62
} 
narrative fidelity are analogous to the concepts of dramatic probability and verisimilitude, "The difference between imaginary characters and real ones is not in the narrative from of what they do; it is in the degree of their authorship of what form and of their own deeds.)

5. The world as we know it is a set of stories that must be chosen among in order for us to live life in a process of continual re-creation. In short, good reasons are the stuff of stories, the means by which humans realize their nature as reasoning valuing animals ${ }^{3}$

The "rational" world's offerings would be shaped like this:

1. Humans are essentially rational beings.

2. The paradigmatic mode of human decision-making and communications is argument-discourse that features clear-cut inferential or implicative structures.

3. The conduct of argument is ruled by the dictates of situations-legal, scientific, legislative, public, and so on.

4. Rationality is determined by subject-matter knowledge, argumentative ability, and skill in employing the rules of advocacy in the given fields.

5. The world is a set of logical puzzles that can be solved through appropriate analysis and application of reason conceived as an argumentative construct. In short, argument as product and process is the means of being human, the agency of all that humans can know and realize in achieving their telos. The philosophical ground of the rational world paradigm is epistemology. Its linguistic materials are self-evident propositions,

${ }^{3}$ Fisher, 64. 
demonstrations, and proofs-the verbal expressions of certain and probably knowing. ${ }^{4}$

I think looking at these two models of rationale, not to prove one more accurate than the other, but to analyze our culture in America, opens up some interesting ideas. These ideas allow for the possibly that: Stories we tell ourselves and each other establish a meaningful lifeworld. Narrators, conflicts, resolutions, and the styles in which stories are told may relate the truth.

Possibly, we have entered a time that reality has been replaced by story. This notion was predicted as early as 1934 by the German art historian Erwin Panofsky "If all the serious lyrical poets, composers, painters and sculptors were forced by law to stop their activities, a rather small fraction of the general public would become aware of the fact and a still smaller fraction would seriously regret it. If the same thing were to happen with the movies, the social consequences would be catastrophic." Jean Baudrillard would definitely argue that we are at this point as a culture.

Baudrillard is an author and cultural theorist who believes that new media practices may have rearranged our sense of space and time. Over the course of the past thirty years, Baudrillard has introduced the idea of the hyper-real. Cinema and television, or media is the world. Media dissolves into life, and life dissolves into media. Fiction is "realized" and

\footnotetext{
${ }^{4}$ Fisher, 59.

${ }^{5}$ Panofsky quoted in Corrigan, A Short Guide to Writing About Film, 1.
} 
the "real" becomes fictitious. Simulation replaces production. ${ }^{6}$ The "real" makes attempts to be "realer" than "real" and thus we enter hyper-real. This idea of hyper-reality may be best and most simply defined as reality replaced by simulation, acknowledged and accepted by us as Americans.

Baring in mind the fact that media (and I add to this list the photographic image) shapes our world, I feel undoubtedly that this blending of life and fiction rearranges our memories, our stories, and the way we "test narrative fidelity."7 Our stories become a part of the hyperreal.

One can begin to understand the hyper-real through the example of special effects and computer-generated imagery. We recognize the fact that media exaggerates the real for the sake of story. The question may be raised then why I personally add the photographic image to this list of story telling media that shapes our world? In brief, I think that no matter what the advances in the photographic medium are, we still place the importance of truth, proof, or evidence on an image. The still image is not thought of as the tool of the narrator, but thought of as the tool of the documentarian. I see the still image as a single frame of a great narrative. A still image that the photographer controls and directs. A still

\footnotetext{
${ }^{6}$ Sarap, An Introductory Guide to Post-Structuralism and Postmodernism, 165.

${ }^{7}$ Fisher, 64 .
} 
image that allows us to "establish a meaningful life-world."8 These relationships are what I am exploring in my newest body of work titled:

American Standard.

${ }^{8}$ Fisher, 62. 


\section{American Standard}

In my current body of work, I use the photographic image as a director uses the medium of film (moving image). Location scouting, casting, lighting, directing, editing, and processing all become intricate parts of the work, all to lead to a single solitary frozen moment in time that I believe creates a story. Story, not in a fictional sense, but more in the vein of creative non-fiction, as the stories I tell come from a personal past.

In the work, I ask the viewer to examine the photograph and, just as Fisher asks, examine its narrative fidelity. I choose to use the medium of photography to challenge prefabricated definitions of the frozen image. I believe when most people think of a photographic image, they consider it as some sort of symbolic report, truth, or record of an event. In response to this I believe most images are sponsored or authored in some way. Subject matter is manipulated to delineate or embellish story.

Authoring of an image may be as simple as gathering the children around the cake for the good old fashioned happy birthday shot. This classic photograph lives long in our memories as a document of the event. Is this really a document though, or is this a fabricated moment conceived and contrived to look back on one day for the sake of story? Take for example the famous photograph by Joe Rosenthal "Raising of the Flag on 
Iwo Jima" (see figure 01). This is one of the most famous documents in photographic history. Unfortunately this is not a document of the event at all. This photo, which is now the subject of a feature film, was authored. The image we know so well was shot at a different location, and not even on the same day, as the historical event depicted.

The authoring of an image for me begins to more openly reference some of the things associated with story telling, and our culture's advancement toward the aforementioned blending of real life and media. I see the authoring of the image more like Alexander Astruc did when he was arguing for the director as the auteur of cinema. In a 1948 essay titled "La Camera-Stylo (The Camera-Pen)", Astruc wrote that cinema had reached a maturity that allowed image makers to write with their cameras like writers with pens, and that now images would come from a more personal place, technology, cast, and crew, would be no more than tools of the artist. ${ }^{9}$ Image authoring for myself allows me to enter the role of the director in hopes that the images I create will inspire the viewer to examine their role as a homo narran.

The "American Standard" series is a product of a very carefully and deliberately executed plan for each single individual image. The process begins very simply with the recollection of a memory. While recalling the event I check the narrative complexity and rationale of the event against a stereotypical "American" standard of what "should be" in our culture. I

\footnotetext{
${ }^{9}$ Thompson/Bordwell, Film History, An Introduction, 415.
} 
often choose stories a bit "out of the norm" that are intriguing enough to tell. Next I storyboard from the memory looking for the climactic point of interest that led me back to revisit the particular event. Once this point is established I focus on a single solitary moment that I can translate to the chromogenic print taking full advantage of its stillness. I believe this is one of the photograph's greatest strengths; it has the ability to hover in space and time with no beginning and no ending allowing the viewer to create a personal relationship with each image.

With the decisive moment established, I begin the process of location scouting. This is a very vital part of the work for me as I look to recreate "a mise-en-scene" (theatrics of space as that space is constructed for the camera ${ }^{10}$ ) that will hold up to the original and not damage the integrity of the narrative. Consider for example the image "untitled" (woman in rose dining room)(see figure 02). Weeks were spent scouting an interior dwelling that possessed the key elements; the rose wallpaper, doorway establishing another room, and chandler. These items were key to the tension of the memory and story that I wished to tell. I used the doorway to reference the depth of not only the location but that of the implied tension. This idea of "staging in depth" is a vital part of the image for me as "An image is an abstraction of the world in two dimensions. It takes away a dimension from the real world, and by this

${ }^{10}$ Thompson/Bordwell, 56 
very fact the image inaugurates the power of illusion." ${ }^{11}$ By using the "staging in depth" approach to establish the scene, I feel the viewer accepts the point of view of the camera as their own and employs their sense of imagination to complete the dimensional loss of the image, i.e., to make the photograph real to themselves.

With the location established, my next step is to cast the central figure. As with the location scouting, the casting process is one I find important in relation to the narrative integrity. For example, in the image "untitled" (man with gun) (see figure 03) the central character needed to be a middle-aged man with slight signs of economic hardship. Without this look the character would not blend with the highly-staged location. Costume was selected from the local thrift store to complete the entire feel of the character.

With the two most difficult elements of the image in place, stage and character, I next establish a shoot date. The exposure itself may happen in a $250^{\text {th }}$ of a second but the day is full of lighting and manipulating the environment to match my vision of the particular image. This process, being very difficult to manage, often calls for me to hire assistants. The assistants mainly attend to the large amount of lighting equipment and difficult light metering situations that blend natural light and the studio strobe equipment. The image "untitled" (woman in blue shirt) (see figure 04) is a good example of use of assistants as five

${ }^{11}$ Zurbrugg, Jean Baudrillard Art and Artefact, 9. 
different lighting sources were needed to create the dusk ambience of the image.

After the exposure process is completed the images are evaluated and edited down to the single frame that I am satisfied with. This solitary moment is then imported into the computer for finish work. The image undergoes intensive processing to deliver the stylized final look of the piece. With computer software I use as many different techniques as needed in an attempt to make the final pieces as hyper-real as possible. Software that allows tonal mapping, channel selections, lightness gradations, etc. all add to the final look which often has me adjusting each pixel of the image in an attempt to deliver the exaggerated reality of the photograph (see figure 05).

Once all of the steps involved with the creation of each image have been completed the output of the piece takes place. In response to my opinions that the photographic image is still observed as a truthful representation of what was directly in front of the lens I output each image as a traditional Chromogenic print. I believe that most people accept a traditional photograph and are more leary of digital print. I want the work to speak of image in a physical and metaphorical way. My cues come from the mass media, just as the mode of operation does, so I am careful to display the images all being of horizontal ratio and large scale. This large scale horizontal ratio is meant to reference the cinema, as well as the more contemporary televisions. Contrary though, I use the aspect 
ratio of smaller photographic prints that one might obtain from the local one-hour drug-store processor, perpetuating the notion of simulation through images and story. 


\section{Influential Artists}

During the process of creating work for the series

"American Standard" I was influenced by many artists and artists'

writings. These artists create works that are not only similar to mine in form but also in content. They speak about their work as a way to recreate their world of stories through the image.

The most contemporary of all the artists that I see as influential would be Gregory Crewdson (born 1962). Crewdson takes my comparisons of photo and film a step further. Crewdson does not touch any aspect of his work but acts only as director. Large production units are used to create his work on sound-sets. Cinematographers, lighting directors, casting agents, stagehands, extras, digital production units, are all common in the making of one image (see figure 06). Crewdson's work is important as it takes in account the notion of "image" being one that is constructed as most of his work is based on the suburban façade. With use of the highly controlled environment Crewdson draws into question where our notion of reality comes from, what we see, or what we construct subconsciously from alternative sources.

Jeff Wall (born 1946) is also an important influence. Wall constructs large-scale light box photographs depicting, on first glance, mundane cultural scenes (see figure 07). After closer examination one 
would fine art historical references in all of Wall's work. This is due to the fact that he was often dropped off at the library as a youth. Wall was not able to read at this early age and was attracted to the images in the art history books. I draw from Wall this idea of letting the past especially that of childhood, become the driving force of the work. Wall's fascination with early works of art mimics that of Crewdson's and the cinema. Contrary to Crewdson, Wall does create his constructed scenes with a more hands on approach similar to that of the authors of early works of art.

Cindy Sherman (born 1954) is another artist that I feel important to this vein of working. Sherman makes frozen moments of time that look as if they were plucked from a feature film, or television situation comedy. She very early on recognized the strength of the image to control. She mimics the cinema in such a way that we see her understanding of the new mold of cinema shaping culture. Sherman used this aspect of control to question many issues of the woman's role in society, but just as important to question how the media's creation becomes simulated in the real world (see figure 08). 


\section{Conclusion}

This present body of work is meant to focus on the individual within the American culture as a story telling animal, and question our cultures acceptance of the photographic image. Through the use of implied narrative in each photographic image I hope to make the viewer question all accounts of their being. I want the viewer to begin to understand that regardless of the form, all accounts or recounts constitute a story. These stories we tell each other and ourselves are all in hopes of establishing a meaningful life-world. These stories have within them a narrator, cast of characters, conflicts, and resolutions, all telling a bigger story of the American condition. The end question being how much of our selves is real and how much is hyper-real. 


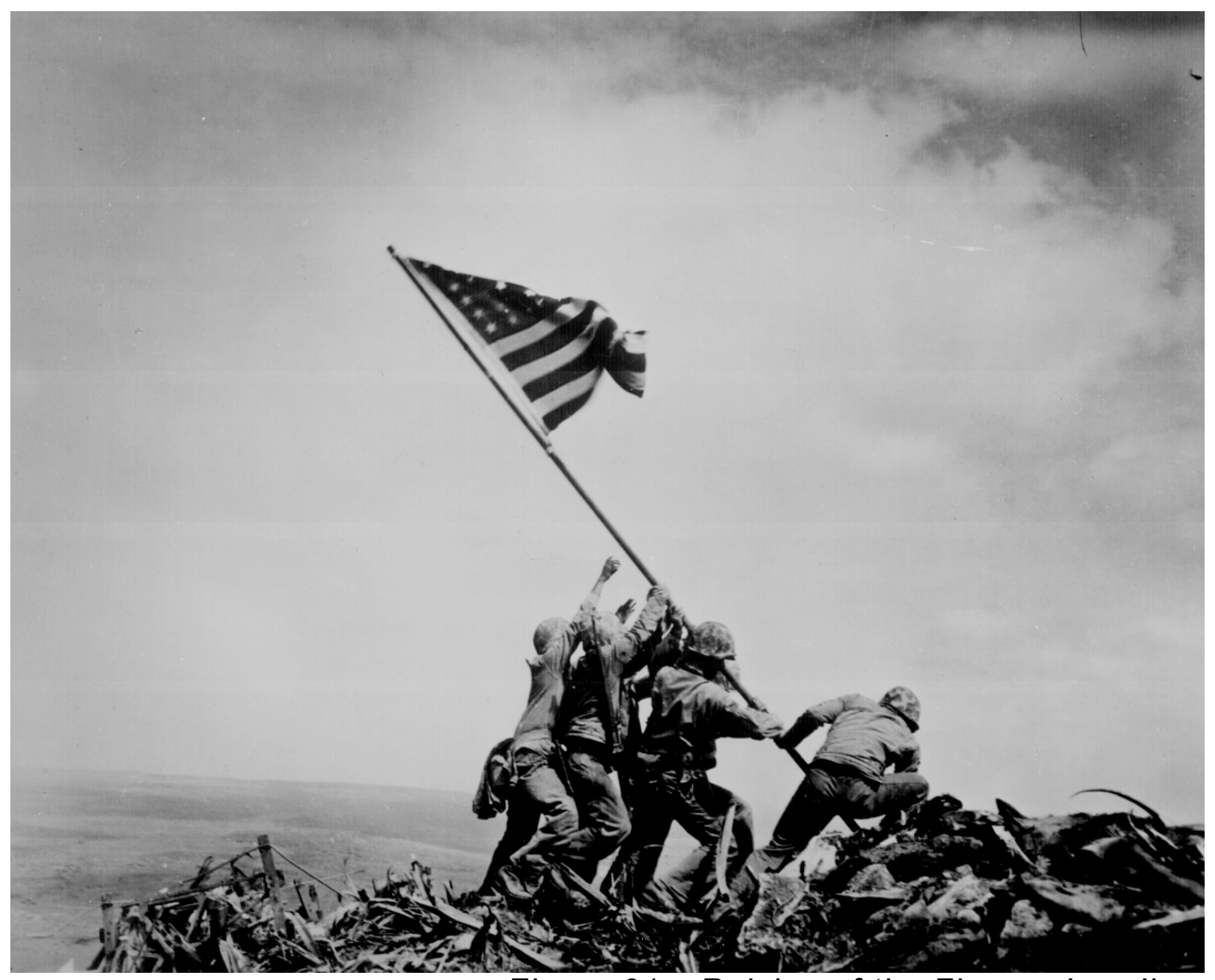

Figure 01. Raising of the Flag on Iwo Jima 


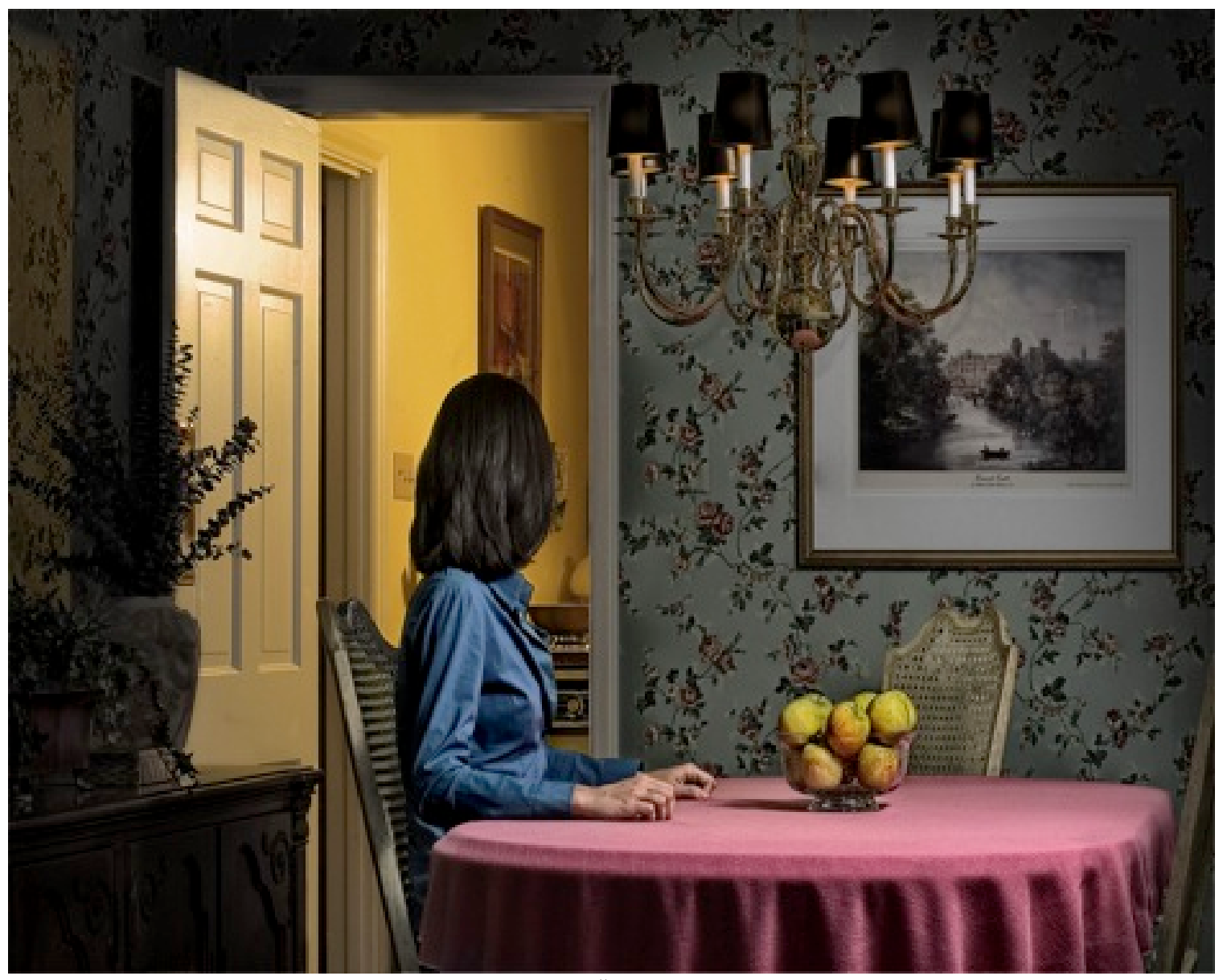

Figure 02. "untitled" (woman in rose dining room) 


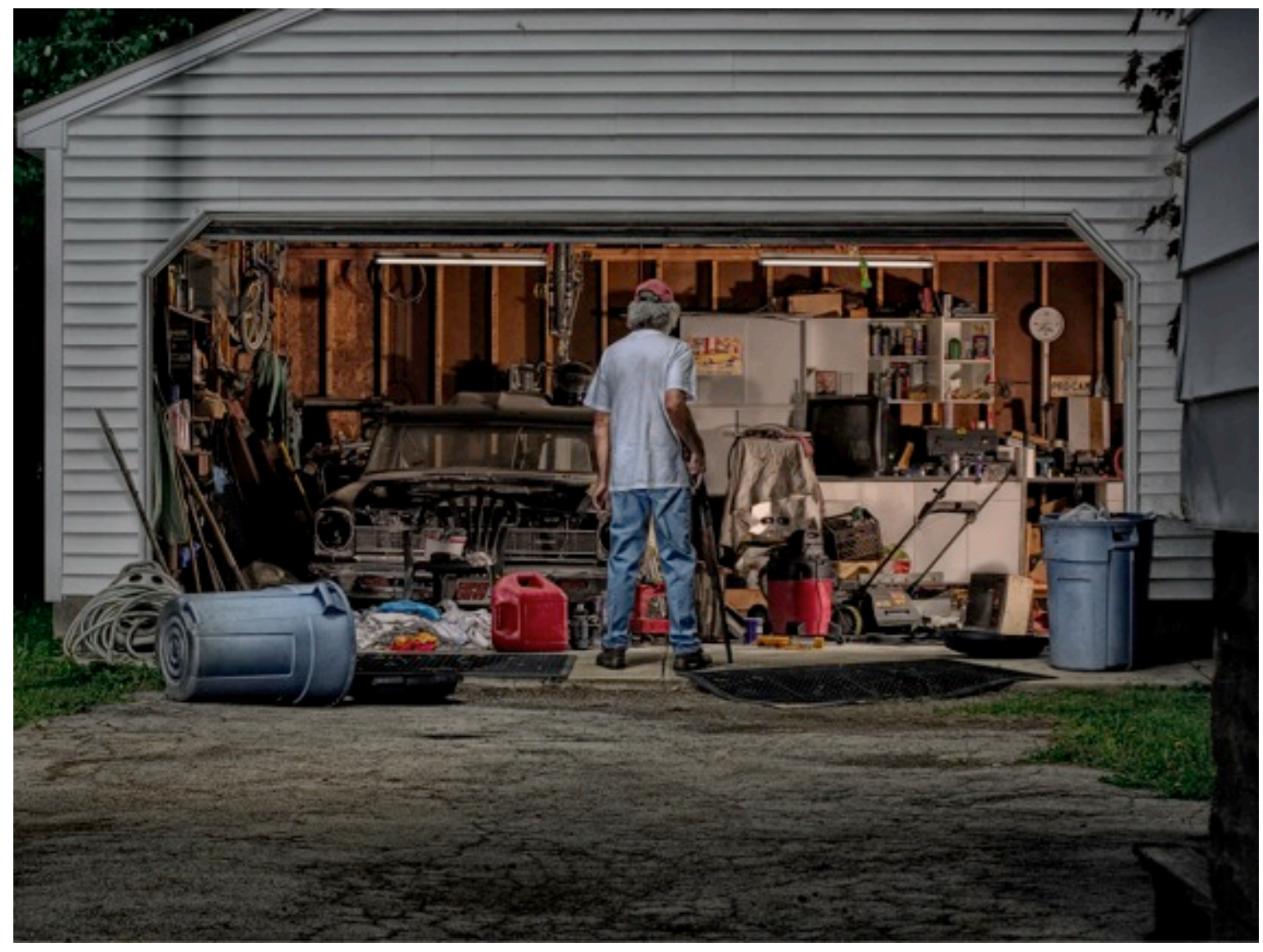

Figure 03. "untitled" (man with gun) 


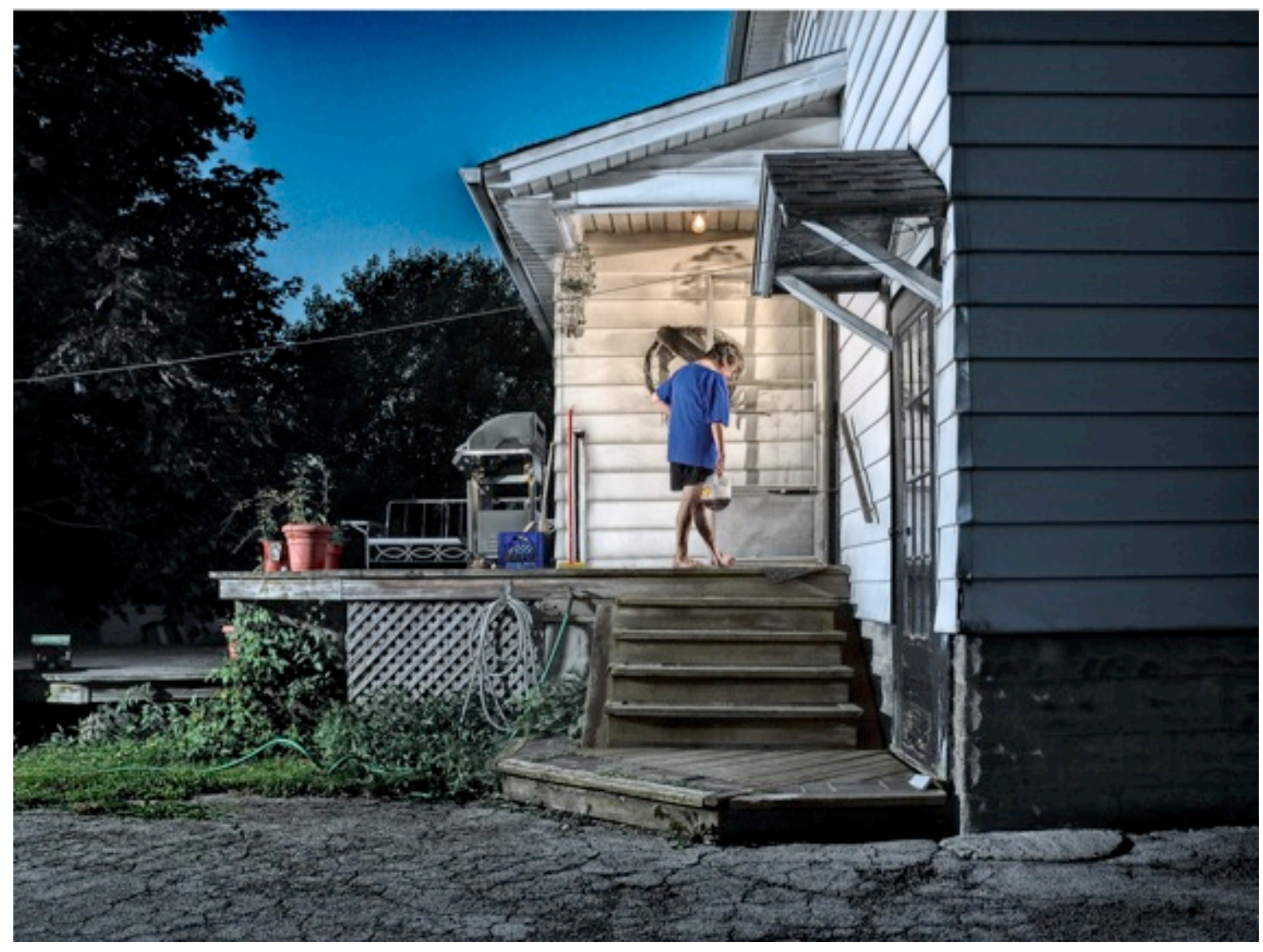

Figure 04. "untitled" (woman in blue shirt) 


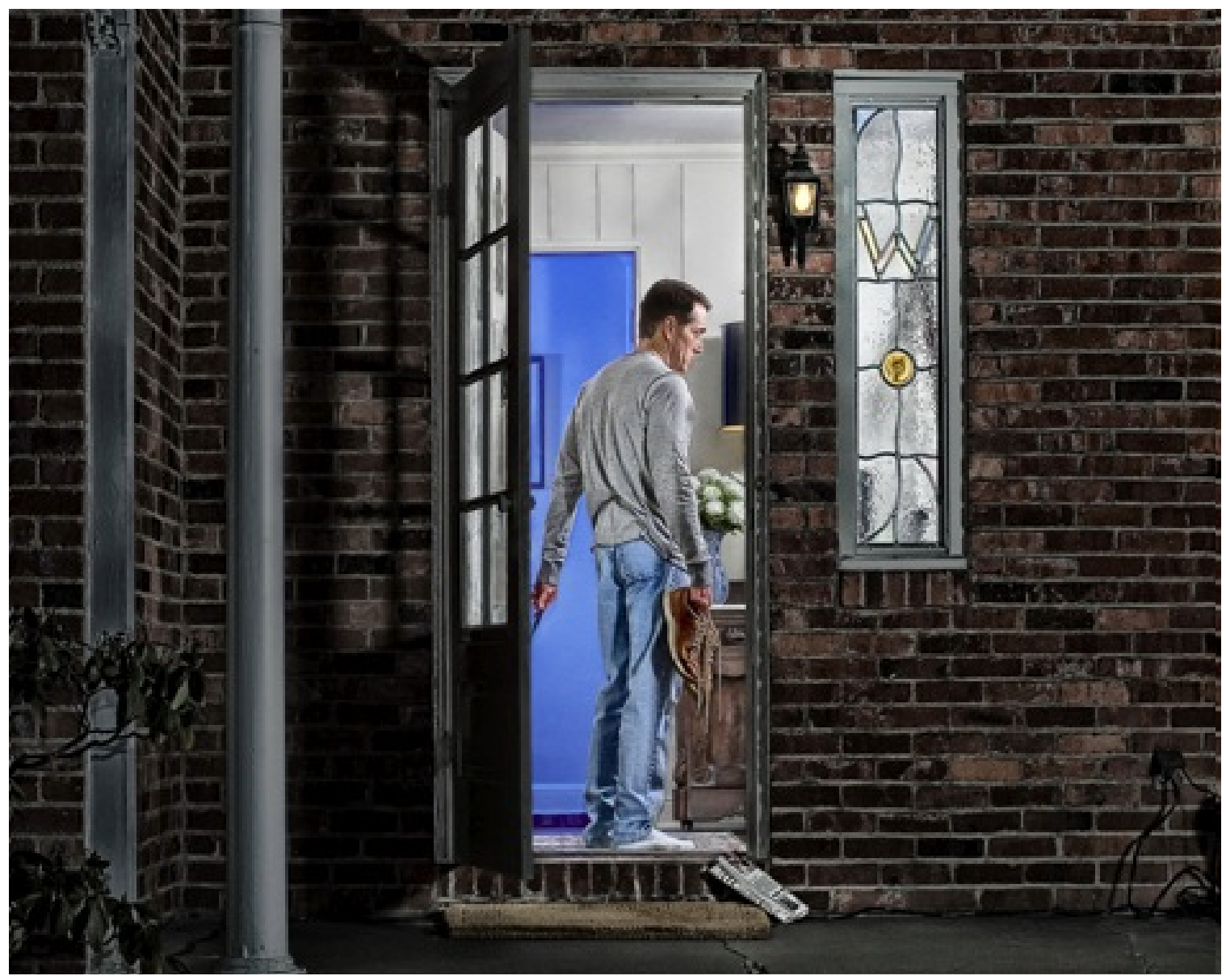

Figure 05. "untitled" (man at door with shoes) 


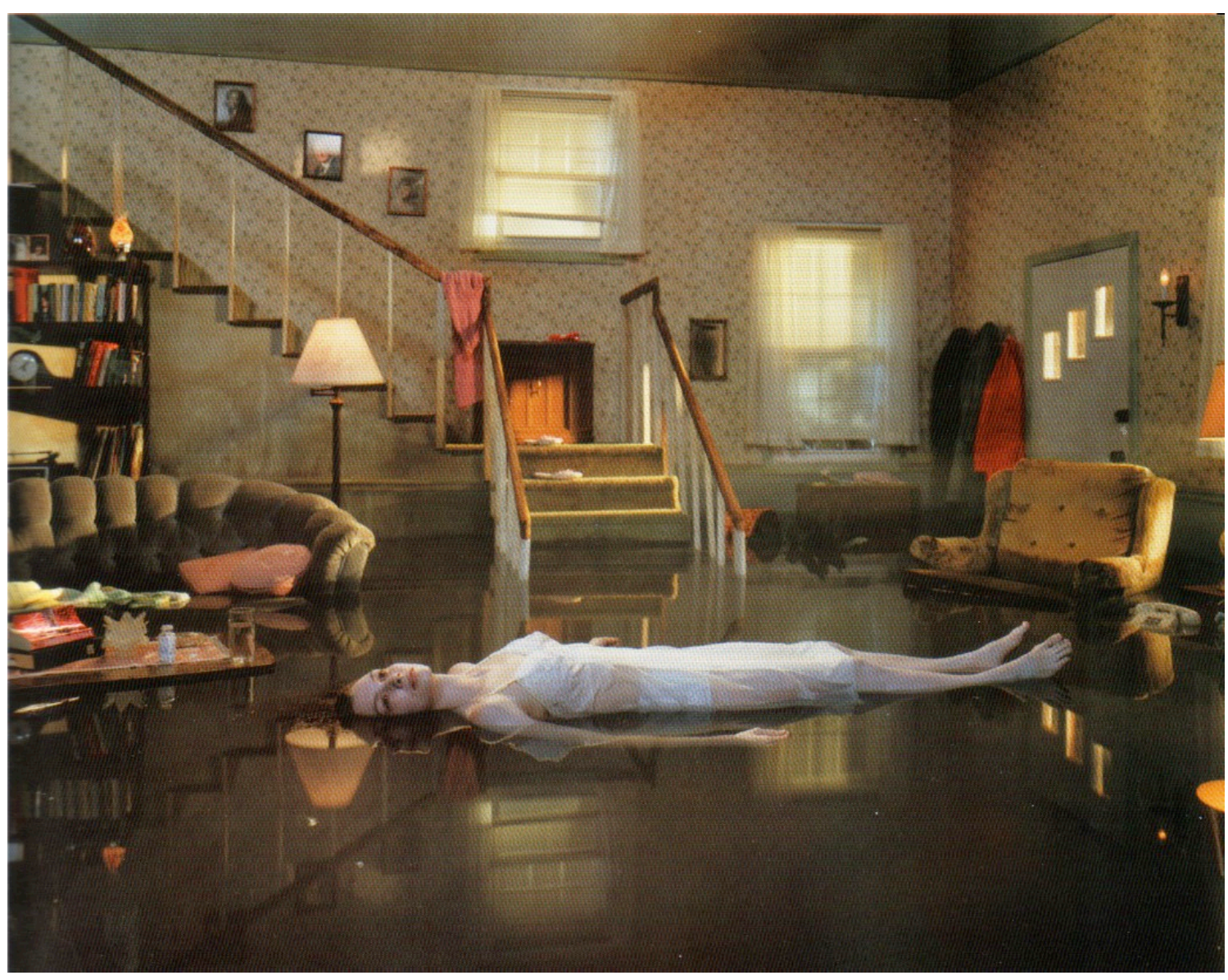

Figure 06. "Drowned Ophelia" 


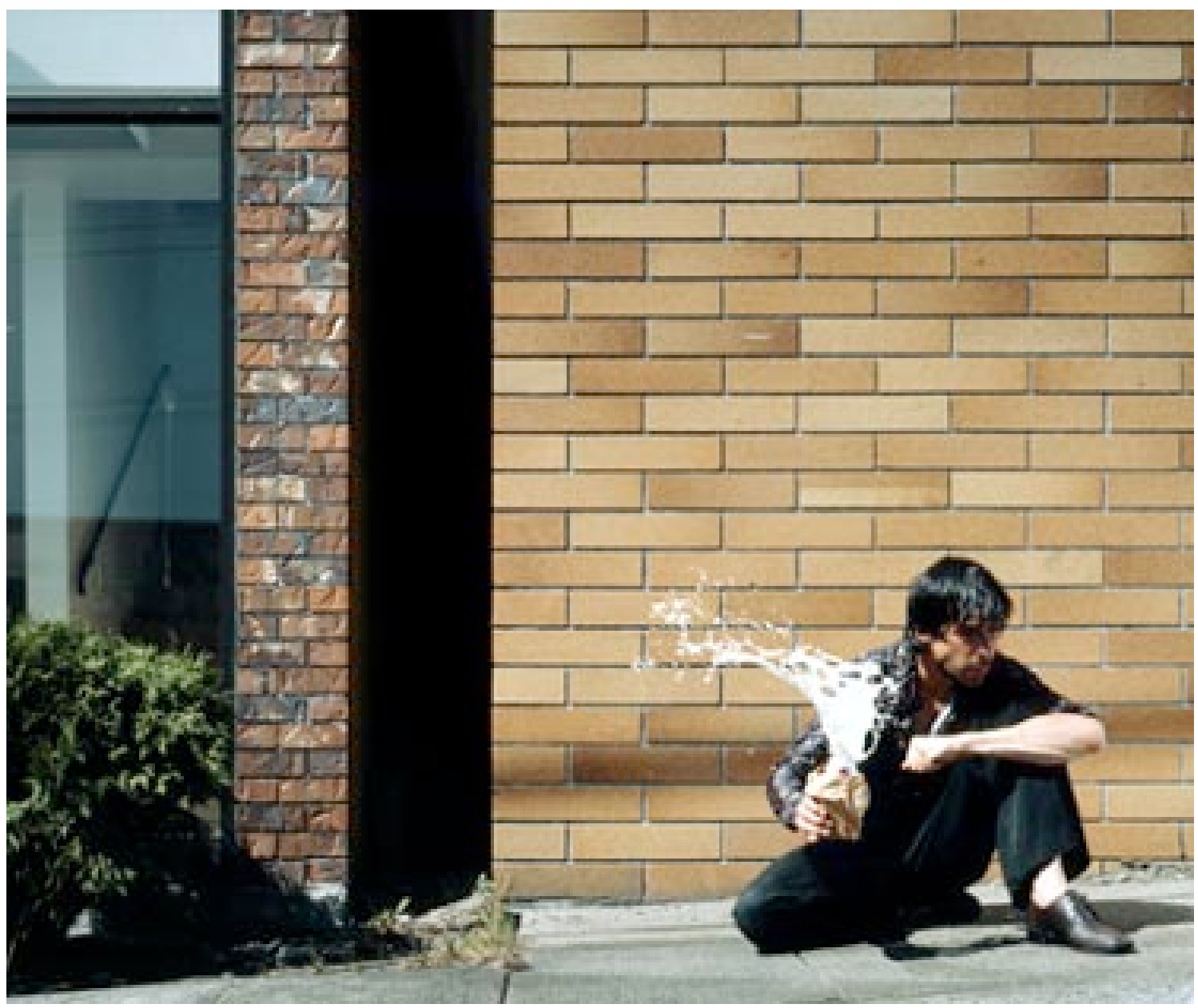

Figure 07. "Milk" 


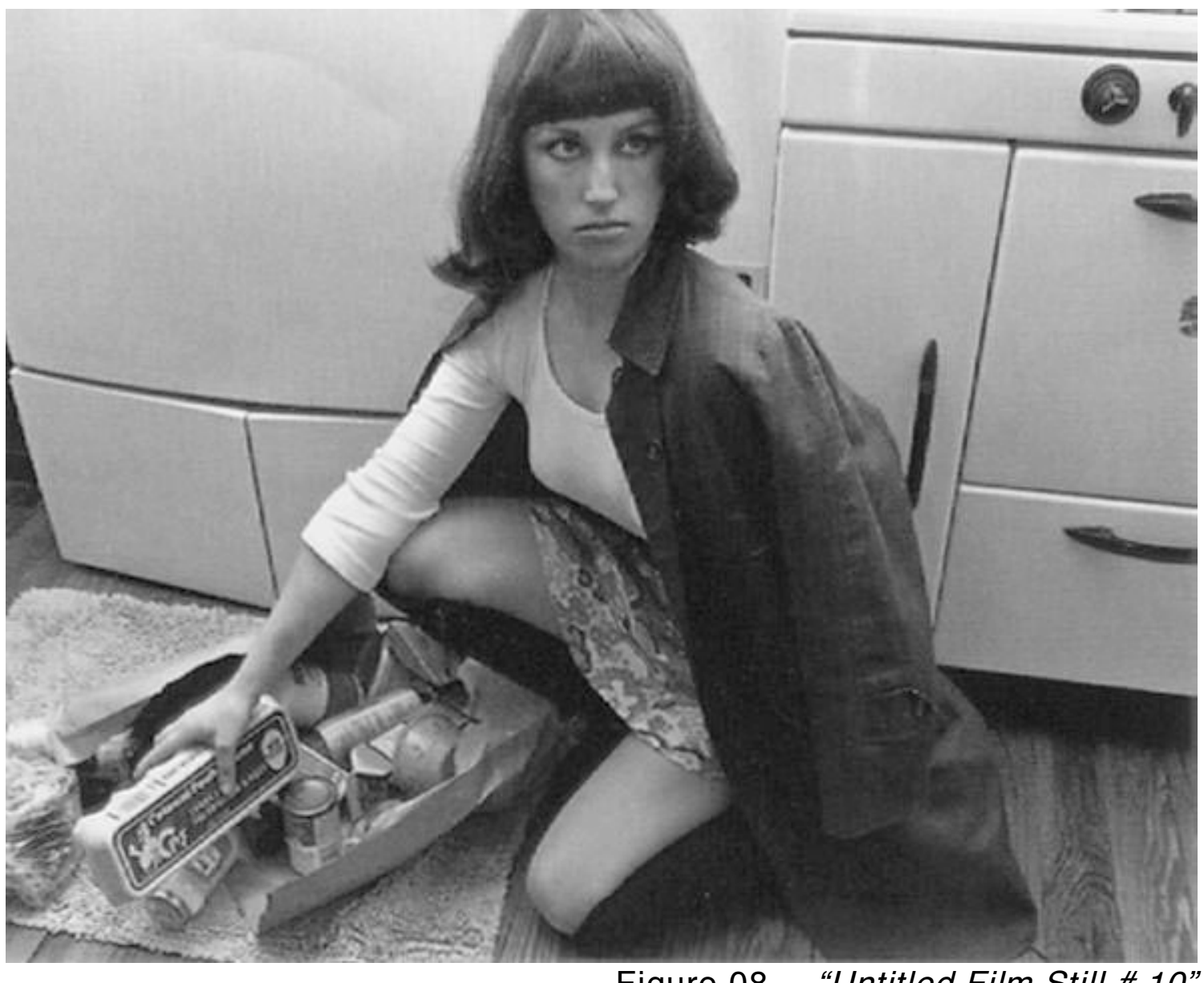

Figure 08. "Untitled Film Still \# 10" 


\section{Bibliography}

Corrigan, Timothy. A Short Guide to Writing about Film. Pearson Longman, 2006

Fisher, Walter. Human Communication as Narration: Toward a Philosophy of Reason, Value, and Action. University of South Carolina Press, 1987

Lipovetsky, Gilles. Hypermodern Times. Polity Press, 2005

Moody, Rick. Hover. ARTSACE books, 1998

Sarup, Madan. An Introductory Guide to Post-Structuralism and Postmodernism. Pearson Education Limited, 1993.

Thompson, Kristen and Bordwell, David. Film History, An Introduction. McGraw-Hill, 2003

Zubrugg, Nicholas. Art and Artefact. SAGE Publications, 1998 


\section{John A. Pascarella \\ 1001 Milton Rd \\ Pittsburgh, PA 15234 \\ (412) 901-9303 \\ johnpascarella@mac.com}

\section{Education}

$\begin{array}{llll}\text { M.F.A. } & \text { Inter-Media } & \text { West Virginia University } & \text { Morgantown, West Virginia } \\ \text { B.F.A. } & \text { Photography } & \text { Youngstown State University } & \text { Youngstown, Ohio }\end{array}$

\section{Academic Teaching Experience}

$2006 \quad$ Adjunct Professor of Digital Photography, College of Creative Arts, West Virginia University, Morgantown West Virginia Instructor of record, Electronic Media 2, College of Creative Arts, West Virginia University, Morgantown West Virginia Instructor of record, Advanced Drawing, College of Creative Arts, West Virginia University, Morgantown West Virginia

2005 Instructor of record, Independent Study, College of Creative Arts, West Virginia University, Morgantown West Virginia Adjunct Professor of Photography, College of Creative Arts, West Virginia University, Morgantown West Virginia Instructor of record, Introduction to Two Dimensional Design, College of Creative Arts, West Virginia University, Morgantown West Virginia

2004 Instructor of record, Electronic Media 1, College of Creative Arts, West Virginia University, Morgantown West Virginia

\section{Professional Experience}

2002-2004 Professional Digital Imaging Technician, Sukolsky Brunelle / Benchmark Color Lab, Pittsburgh, Pennsylvania,

\section{Selected Honors, Awards, Fellowships, and Grants}

\begin{tabular}{|c|c|}
\hline 2006 & $\begin{array}{l}\text { National Award of Honor - Best of Show, Westmoreland Art Nationals, Founders Hall, Westmoreland Community College, } \\
\text { Youngwood, Pennsylvania } \\
\text { Full Teaching Assistant Scholarship, College of Creative Arts, West Virginia University, Morgantown West Virginia }\end{array}$ \\
\hline 2005 & Full Teaching Assistant Scholarship, College of Creative Arts, West Virginia University, Morgantown West Virginia \\
\hline 2004 & Full Teaching Assistant Scholarship, College of Creative Arts, West Virginia University, Morgantown West Virginia \\
\hline 2002 & $\begin{array}{l}\text { Deans Award for Outstanding Performance in the Arts, Youngstown State University, Youngstown, Ohio } \\
\text { Butler Museum of American Art Award, Best of Show, Youngstown State University Student Show, } \\
\text { Mc Donough Museum of Art, Youngstown, Ohio }\end{array}$ \\
\hline 2001 & $\begin{array}{l}\text { Butler Museum of American Art Award, Best of Show, Youngstown State University Student Show, } \\
\text { Mc Donough Museum of Art, Youngstown, Ohio }\end{array}$ \\
\hline 2000 & $\begin{array}{l}\text { John M. Mitchel Memorial Grant, Best Photograph Award, Youngstown State University Student Show, } \\
\text { Mc Donough Museum of Art, Youngstown, Ohio }\end{array}$ \\
\hline
\end{tabular}

\section{Selected Juried and Curated Exhibitions}

2006 American Standard, Mesaros Gallery, College of Creative Arts, West Virginia University, Morgantown West Virginia Westmoreland Arts Nationals, Founders Hall, Westmoreland Community College, Youngwood, Pennsylvania Mysterious Object, Quarterly Online Journal, Based in Minneapolis, St-Paul

Entre Nous, Mesaros Gallery, College of Creative Arts, West Virginia University, Morgantown West Virginia China, Levels of Discernment, Kent State University, East Liverpool, Ohio

2005 What You Will, Mesaros Gallery, College of Creative Arts, West Virginia University, Morgantown West Virginia Westmoreland Arts Nationals, Founders Hall, Westmoreland Community College, Youngwood, Pennsylvania

2004 China, Levels of Discernment, Weyers-Sampson Art Gallery, Theil College, Greenville Pennsylvania Fleeting, Mountain Lair Gallery, West Virginia University, Morgantown West Virginia

2003 China, Levels of Discernment, Ohio Dominican University, Columbus, Ohio China, Levels of Discernment, Butler Institute of American Art, Salem, Ohio China, Levels of Discernment, Todd Hall, Youngstown State University, Youngstown, Ohio

2002 China, Levels of Discernment, Mc Donough Museum of Art, Youngstown, Ohio Toy and Technology Show, Cuyahoga Community College, Cleveland Ohio 2002 Graduating Seniors Honors Exhibition, Mc Donough Museum of Art, Youngstown, Ohio $66^{\text {th }}$ Annual Student Show, Mc Donough Museum of Art, Youngstown, Ohio, Butler Museum of American Art Award Focal Point, West Minster College, New Wilmington, Pennsylvania Focal Point, Bliss Gallery, Youngstown State University, Youngstown, Ohio

$2001 \quad$ Mural Show 01, Millworks Gallery Inc., Akron, Ohio $65^{\text {th }}$ Annual Student Show, Mc Donough Museum of Art, Youngstown, Ohio, Butler Museum of American Art Award

$200064^{\text {th }}$ Area Artist Annual Exhibition, Butler Institute of American Art, Youngstown, Ohio Y2K Fine Art Show, Vine Avenue Gallery, Sharon, Pennsylvania $64^{\text {th }}$ Annual Student Show, Mc Donough Museum of Art, Youngstown, Ohio, John M. Mitchel Memorial Grant Photo Works 2000, Bliss Gallery, Youngstown State University, Youngstown, Ohio Images (Solo Exhibition), Bliss Gallery, Youngstown State University, Youngstown, Ohio $4^{\text {th }}$ Biennial John J. McDonough Works on Paper Exhibition, Mc Donough Museum of Art, Youngstown, Ohio 


\section{Bibliography}

2006 Teaching Photography, Glenn Rand and Richard Zakia, Focal Press, ISBN: 13: 978-0-240-80767-6, Pg. 134, 350

2002 China Levels of Discernment Catalogue, 5 images, artist statement, and resume, published by Ohio Arts Council

2001 Photographers Forum, Best of College Photography Annual 2001, Serbin Publications, California

Contemporary Art Interview, CBS WKBN TV Channel 27, Youngstown, Ohio

\section{Selected Public and Private Collections}

Mc Donough Museum of Art, Youngstown, Ohio

Greg Moring (private collection), International Artist

\section{Exhibitions Curated}

2005 15/12 Electronic Media, Mountain Lair Gallery, West Virginia University, Morgantown West Virginia

2001 Focal Point (assistant to curator) Bliss Gallery, Youngstown State University, Youngstown, Ohio

\section{Professional Organizations}

College Art Association (member since 2004)

Society for Photographic Education (member since 2004)

Silver Eye Center For Photography (member since 2006)

Websites (containing work)

Zone Zero, http://www.zonezero.com/comunity/portfolios/experimental/pascarella/1en.html

Pascarella Studio, http://web.mac.com/johnpascarella

\section{Technical Attributes}

Commercial digital image manipulation, large format digital Chromogenic printing, digital Dy Sublimation printing, large format digital Ink Jet printing, commercial design and packaging, digital image seminar instructor, digital workflow seminar instructor, digital lab creation

Traditional and Non Traditional silver processes

Traditional Color Head Chromogenic processes

Purchasing, Installation, and maintenance of devices in both traditional and digital lab environments

\section{Professional Service}

SITE '05, Summer Institute for Teacher Education in the arts, Assisted Professor Terry Barrett and Dr. William Thomas with establishing program curriculum and serving as technician throughout summer program. 